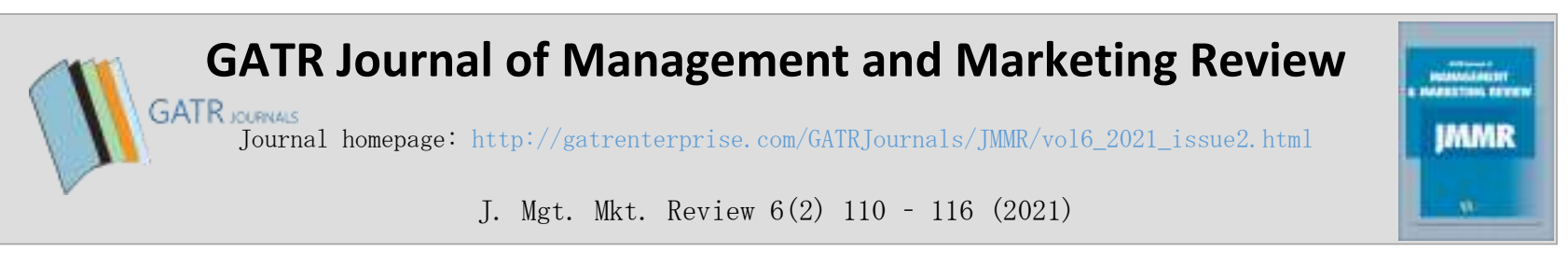

\title{
The Mediating Role of Job Satisfaction in the Relationship between Compensation and Work Environment on Performance
}

\author{
Ilzar Daud ${ }^{* 1}$ and Nur Afifah ${ }^{2}$ \\ ${ }^{1,2}$ Management Study Program, Faculty of Economics and Business, \\ Universitas Tanjungpura, 78124, Pontianak, West Kalimantan, Indonesia
}

\begin{abstract}
Objective - The purpose of this study is to identify the relationship between compensation and work environment on performance through job satisfaction.

Methodology/Technique - The population in this study is 150 employees from a State-Owned Bank. The sampling method uses census techniques so that the number of samples used is 150 employees. The research data was collected using a questionnaire, which is then analyzed using a path analysis technique (SPSS software) to examine the relationships among the constructs, which are: compensation, work environment, job satisfaction and performance.

Findings -The results of this study indicate that compensation has a significant relationship between job satisfaction, and the work environment has a significant relationship on job satisfaction. The results also prove that compensation has no relationship on performance, work environment has a significant relationship on performance, and job satisfaction has a significant relationship on performance. The results of this study also indicate that as an indirect effect, compensation has a significant relationship on performance through job satisfaction and the work environment has a significant relationship on performance through job satisfaction.

Novelty - Previous studies have been carried out in many western countries, raising doubts about generalizations in the same research results in developing countries such as Indonesia. Therefore, the novelty in this study is carried out in the context of developing countries, especially in State-Owned Banks in West Kalimantan, Indonesia.

Type of Paper: Empirical.

JEL Classification: L22, M12, M19.

Keywords: Compensation; Work Environment; Job Satisfaction; Performance

Reference to this paper should be made as follows: Daud, I; Afifah, N. (2021). The Mediating Role of Job Satisfaction in the Relationship between Compensation and Work Environment on Performance, J. Mgt. Mkt. Review, 6(2) $110-$ 116. https://doi.org/10.35609/jmmr.2021.6.2(2)
\end{abstract}

\section{Introduction}

In the era of globalization, competition between organizations is increasing. Organizations compete to get the most out of their performance. A competitive work environment encourages an organization to continue to improve its performance. However, the performance of an organization comes from the performance of the employees themselves because human capital is the most important resource within an organization. Therefore, human capital is the key to organisational success. According to Onukwube (2012), employees who perform well will be supported by high job satisfaction in their work because job satisfaction is one of the main factors within an organization.

\footnotetext{
* Paper Info: Revised: March 11, 2021

Accepted: June 30, 2021

* Corresponding author: Ilzar Daud

E-mail: ilzar_daud@yahoo.com

Affiliation: Management Study Program, Faculty of Economics and Business, Universitas Tanjungpura,

78124, Pontianak, West Kalimantan, Indonesia
} 
Several factors can influence employee performance, such as: compensation, work environment, and job satisfaction. According to Mathis and Jackson (2007), effort is made to increase compensation which is an important factor affecting why people work in an organization. Dessler (2010) states that 'employee compensation refers to forms of payment for employees and comes from their work'. According to Mondy (2008), 'compensation includes all gifts given to employees as a form of appreciation for their work'. The results of previous studies show that compensation affects performance (Hameed et. al., 2014; Teclemichael $\&$ Soeters, 2006).

According to Terry (2006), the work environment refers to the forces that influence, either directly or indirectly, on the performance of an organization. The organization must ensure the factors that contribute employee's performance are fulfilled optimally. One such factor is work environment. A comfortable work environment can lead to an increase in performance. It influences the way employees complete their work. Research conducted by Kiruja and Karanja (2013) proves that there is a relationship between work environment and employee performance; if work environment supports the work atmosphere, the employee's performance will increase.

Job satisfaction can be achieved if individuals and aspects of the job support each other so that job satisfaction can be obtained from how individuals feel about their work. If an employee is satisfied with their job, performance can gradually become more productive. According to Robbins (2009), 'job satisfaction is the attitude that workers have about their job'. This is the result of their perception of their job. Research conducted by Javed et. al. (2014) proves that job satisfaction has an effect on employee performance.

The explanation above shows that previous studies on compensation, work environment, job satisfaction and performance have occurred in many western countries, giving rise to doubts about the generalizability of research findings when applied in developing countries, such as Indonesia. Therefore, further studies regarding compensation, work environment, job satisfaction, and performance are very important for a developing country like Indonesia, particularly in respect of State-Owned Banks.

\section{Literature Review}

\subsection{Compensation and Job Satisfaction}

Compensation is remuneration received by an employee as a result of performance in the organization in the form of salaries, wages, bonuses, incentives, and other forms of rewwward. Compensation is an important factor in increasing job satisfaction and retaining employees. According to Ibrahim and Boerhaneoddin (2010), compensation encourages employees to keep working for long periods of time. Results from previous research shows that there is a positive relationship between compensation and job satisfaction (Salisu et. al., 2015). According to Mabaso and Dlamini (2017), compensation has a significant effect on employee job satisfaction. Based on the explanation above, the following hypothesis is proposed:

H1: Compensation has a significant relationship with job satisfaction.

\subsection{Work Environment and Job Satisfaction}

According to Terry (2006), work environment can be defined as the factors that affect, either directly or indirectly, the performance of an organization or company. A good work environment will affect job satisfaction. A conducive work environment provides a sense of security and enables employees to perform optimally. The work environment can also affect employee emotions. If an employee enjoys the work environment where they work, then the employee will feel at home in their workplace to carry out activities so that work time is used effectively, and employee job satisfaction remains high. Research conducted by Agbozo et. al. (2017) found that the physical, social, and psychological work environment has a significant effect on employee job satisfaction. Based on the explanation above, the following hypothesis is proposed: 
H2: Work environment has a significant relationship with job satisfaction.

\subsection{Compensation and Performance}

Compensation is a form of reward given to individuals for carrying out their work. Performance is an implementation of the plans that have been compiled. Performance implementation is carried out by human resources who have the ability, competence, motivation and interests to carry out the required tasks. According to Hameed et. al. (2014), and Teclemichael and Soeters (2006), compensation has an effect on performance. Based on the explanation above, the following hypothesis is proposed:

H3: Compensation has a significant influence on performance.

\subsection{Work Environment and Performance}

A good work environment will provide personal comfort and can increase employee morale. In addition, employees will be more comfortable at work if the existing facilities are clean, quiet, air exchange is good, and the equipment is adequate and relatively modern. Based on research conducted by Kiruja and Kabare (2013), work environment is an important factor in employee performance. Based on the explanation above, the following hypothesis is proposed:

H4: Work environment has a significant influence on performance.

\subsection{Job Satisfaction and Performance}

Job satisfaction refers to an employee's attitude towards their job, which arises based on an assessment of the work situation. The assessment is carried out as a sense of appreciation in achieving one of the important values in the job. Satisfied employees are happy with the conditions of their employment (Robbins, 2009).

According to Robbins (2009), job satisfaction is 'a general attitude towards a person's job which shows the difference between the number of awards received by workers and the amount they believe they should receive.' Job satisfaction is an affective or emotional response to various aspects of a person's job and is not a single concept. A person can be relatively satisfied with one aspect of their job and dissatisfied with one or more other aspects. Researchers have also found that job satisfaction has a positive effect on employee work performance (Javed et. al., 2014), so it can be concluded that employees who have high job satisfaction will perform their job better. Based on the explanation above, the following hypothesis is proposed:

H5: Job satisfaction has a significant influence on performance. 
The following conceptual framework was developed based on the theoretical and empirical evidence:

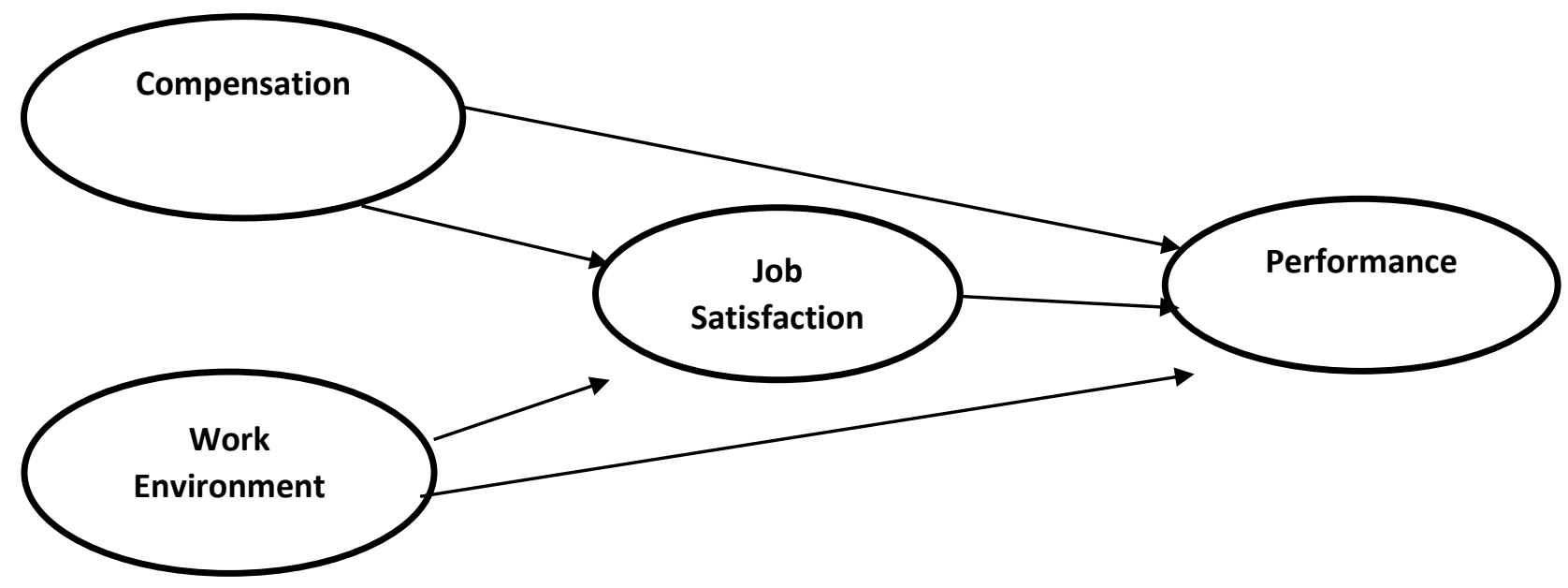

Figure 1. Conceptual Framework

\section{Research Methodology}

This research uses quantitative research methods with a survey research approach. According to Kerlinger and Lee (2000), survey research is research conducted on large and small populations. The population in this study is 150 employees of State-Owned Banks. The sampling method uses a census technique because all populations are sampled so the number of samples taken is 150 employees. The data is collected using a questionnaire. After the data was collected, it is analyzed using a path analysis technique (SPSS software) to examine the relationships among the constructs, which are: compensation, work environment, job satisfaction and performance.

\section{Results and Discussion}

Table 1. Reliability Test

\begin{tabular}{lcl}
\hline \multicolumn{1}{c}{ Variable } & $\begin{array}{c}\text { Cronbach's } \\
\text { Alpha }\end{array}$ & Conclusion \\
\hline Compensation & 0,745 & Good Reliability \\
\hline Work Environment & 0,768 & Good Reliability \\
\hline Job Satisfaction & 0,857 & Good Reliability \\
\hline Performance & 0,884 & Good Reliability \\
\hline
\end{tabular}

Table 2. Regression Analysis First Substructure

\begin{tabular}{lllll}
\hline \multicolumn{6}{c}{ Coefficientsa } & & \\
\hline Model & $\begin{array}{c}\text { Unstandardized } \\
\text { Coefficients }\end{array}$ & $\begin{array}{l}\text { Standardized } \\
\text { Coefficients }\end{array}$ & t & Sig. \\
\hline
\end{tabular}




\begin{tabular}{|c|c|c|c|c|c|c|}
\hline & & B & $\begin{array}{l}\text { Std. } \\
\text { Error }\end{array}$ & Beta & & \\
\hline \multirow[t]{3}{*}{1} & (Constant) & 3,476 & 3,657 & & ,764 & ,273 \\
\hline & Compensation & ,337 & ,214 & ,326 & 3,352 & ,010 \\
\hline & Work Environment & ,436 & ,117 & ,458 & 4,253 & ,004 \\
\hline
\end{tabular}

a. Dependent Variable: Job Satisfaction

Table 3. Regression Analysis Second Substructure

\begin{tabular}{|c|c|c|c|c|c|c|}
\hline \multicolumn{7}{|c|}{ Coefficientsa } \\
\hline \multicolumn{2}{|c|}{ Model } & \multicolumn{2}{|c|}{$\begin{array}{l}\text { Unstandardized } \\
\text { Coefficients }\end{array}$} & \multirow{2}{*}{$\begin{array}{c}\begin{array}{c}\text { Standardized } \\
\text { Coefficients }\end{array} \\
\text { Beta }\end{array}$} & \multirow[b]{2}{*}{$\mathrm{t}$} & \multirow[b]{2}{*}{ Sig. } \\
\hline & & $\mathrm{B}$ & Std. Error & & & \\
\hline \multirow[t]{4}{*}{2} & (Constant) & 23,831 & 5,217 & & 3,841 & ,000 \\
\hline & Compensation & ,437 & , 167 & ,325 & 2,753 & ,081 \\
\hline & Work Environment & ,275 & , 153 & , 148 & ,845 & $\overline{014}$ \\
\hline & Job Satisfaction & ,367 & , 157 & ,347 & 2,353 &, 005 \\
\hline
\end{tabular}

a. Dependent Variable: Performance

Table 4. Direct Effect, Indirect Effect and Total Effect

\begin{tabular}{|c|c|c|c|}
\hline Path & Direct Effect & Indirect Effect & Total Effect \\
\hline $\begin{array}{l}\text { Compensation } \longrightarrow \text { Job } \\
\text { Satisfaction }\end{array}$ & $\begin{array}{l}(0,326)(0,326 \\
\quad=0,106\end{array}$ & 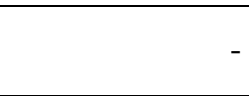 & 0,106 \\
\hline $\begin{array}{l}\text { Work Environment } \longrightarrow \text { Job } \\
\text { Satisfaction }\end{array}$ & $\begin{array}{l}(0,458)(0,458) \\
\quad=0,209\end{array}$ & - & 0,209 \\
\hline $\begin{array}{l}\text { Compensation } \longrightarrow \\
\text { Performance }\end{array}$ & $\begin{array}{l}(0,325)(0,325) \\
\quad=0,105\end{array}$ & - & 0,105 \\
\hline $\begin{array}{l}\text { Work Environment } \longrightarrow \\
\text { Performnce }\end{array}$ & $\begin{array}{l}(0,148)(0,148) \\
\quad=0,021\end{array}$ & - & 0,021 \\
\hline $\begin{array}{l}\text { Job Satisfaction } \longrightarrow \\
\text { Performance }\end{array}$ & $\begin{array}{l}(0,347)(0,347) \\
\quad=0,120\end{array}$ & - & 0,120 \\
\hline $\begin{array}{l}\text { Compensation } \longrightarrow \text { Job } \\
\text { Satisfaction } \longrightarrow \\
\text { Performance }\end{array}$ & $\begin{array}{l}(0,325)(0,325) \\
\quad=0,105\end{array}$ & $\begin{array}{l}(0,326) \quad(0,325) \\
=0,105\end{array}$ & 0,210 \\
\hline $\begin{array}{l}\text { Work Environment } \rightarrow \text { Job } \\
\text { Satisfaction } \longrightarrow\end{array}$ & $\begin{array}{l}(0,148)(0,148) \\
\quad=0,021\end{array}$ & $\begin{array}{l}(0,458) \quad(0,148) \\
=0,067\end{array}$ & 0,088 \\
\hline
\end{tabular}


The results show that in the first substructure, compensation had a significant relationship with job satisfaction, with a significance of 0.010 . The results of this study support the results of research conducted by Salisu et. al., (2015) and Mabaso (2017). Work environment has a significant relationship with job satisfaction, with a significance of 0,004 . The results of this study support the results of research conducted by Agbozo (2017).

In the second substructure, the results show that compensation had no significant relationship with performance, with a significance of 0.081 . The results of this study are not consistent with the results of research conducted by Hameed et. al. (2014) and Teclemichael and Soeters (2006).

Work Environment has a significant relationship with performance, with a significance of 0.014 . The results of this study are in line with previous studies conducted by Kiruja and Kabare (2013). Job satisfaction has a significant influence on performance, with a significance of 0.005 . The results of this study are strengthened by several previous studies, such as research conducted by Javed et. al. (2014). The results of this study also indicate that job satisfaction mediates the relationship between compensation and performance, while the relationship between compensation and performance is mediated by job satisfaction.

\section{Conclusion}

The results show that in the first substructure, there is a significant relationship between compensation and job satisfaction, and a significant relationship between work environment and job satisfaction. In the second substructure, there is no significant relationship between compensation and performance. There is also a significant relationship between work environment and performance and a significant relationship between job satisfaction and performance. Furthermore, the results of this study also indicate that job satisfaction mediates the relationship between compensation and performance, while performance and compensation is mediated by job satisfaction.

The results of this study indicate that in the context of State-Owned Banks, compensation and work environment have a strong effect on employee performance because compensation will provide high motivation for employees to complete their work, and a good work environment will support the completion of work to achieve organizational goals. In addition, a leader can also motivate employees to be more responsible for their work and at the same time create a sense of satisfaction at work which in turn will improve employee performance.

\section{References}

Agbozo, G. K., Owusu, I. S., Hoedoafia, M. A., \& Atakorah, Y. B. (2017). The effect of work environment on job satisfaction: Evidence from the banking sector in Ghana. Journal of Human Resource Management, 5(1), 12-18.

Creswell, J. W., \& Creswell, J. D. (2017). Research design: Qualitative, quantitative, and mixed methods approaches. Sage publications.

Dessler, G., \& Varrkey, B. (2005). Human Resource Management, 15e. Pearson Education India.

Ibrahim, I. I., \& Boerhaneoddin, A. (2010). Is job satisfaction mediating the relationship between compensation structure and organisational commitment? A study in the Malaysian power utility. Journal of Global Business and Economics, 1(1), 43-61.

Hameed, A., Ramzan, M., \& Zubair, H. M. K. (2014). Impact of compensation on employee performance (empirical evidence from banking sector of Pakistan). International journal of business and social science, 5(2).

Balouch, R., \& Hassan, F. (2014). Determinants of job satisfaction and its impact on employee performance and turnover intentions. International journal of learning and development, 4(2), 120-140.

Kerlinger, F. N., \& Lee, H. B. (2000). Foundations of behavioral research. Australia: Wadsworth Thomson Learning. Kiruja, E. K., \& Kabare, K. (2018). Linking work environment with employee performance in public middle level TIVET institutions in Kenya. International Journal of Advances in Agriculture Sciences. 
Mabaso, C. M., \& Dlamini, B. I. (2017). Impact of compensation and benefits on job satisfaction. Research Journal of Business Management, 11(2), 80-90.

Mathis, R. L., \& Jackson, J. H. (2000). Human Resource Management, South.

Mondy, W.R. 2008. Human Resources Management, 10th Edition, Pearson, McNeese State University.

Onukwube, H. N. (2012). Correlates of job satisfaction amongst quantity surveyors in consulting firms in Lagos, Nigeria. Construction Economics and Building, 12(2), 54-54.

Robbins, S. P., \& Judge, T. A. (2009). Organizational Behavior 13th Edition Prentice Hall Publishers.

Salisu, J. B., Chinyio, E., \& Suresh, S. (2015). The impact of compensation on the job satisfaction of public sector construction workers of jigawa state of Nigeria. The Business \& Management Review, 6(4), 282.

Terry, G.R. (2006). Principles of Management. Illinois: Ricard D. Irwin.

Teclemichael Tessema, M., \& Soeters, J. L. (2006). Challenges and prospects of HRM in developing countries: testing the HRM-performance link in the Eritrean civil service. The international journal of human resource management, $17(1), 86-105$. 